\title{
Antimicrobial Resistance and Plasmid Profiles of Campylobacter Species from Infants Presenting with Diarrhoea in Osun State, Nigeria
}

\author{
Olutoyin Catherine Adekunle1, Abiodun A. Onilude ${ }^{2}$ \\ ${ }^{1}$ Department of Medical Microbiology and Parasitology, Ladoke Akintola University of Technology, Ogbomoso, \\ Nigeria \\ ${ }^{2}$ Department of Microbiology, University of Ibadan, Ibadan, Nigeria \\ Email: toyintoro@yahoo.com
}

Received 10 February 2015; accepted 24 February 2015; published 3 March 2015

Copyright (C) 2015 by authors and Scientific Research Publishing Inc.

This work is licensed under the Creative Commons Attribution International License (CC BY).

http://creativecommons.org/licenses/by/4.0/

(c) (i) Open Access

\begin{abstract}
Antibiotic resistance among enteric bacterial pathogens complicates the heavy diarrhoea disease burden. Antimicrobial resistance of Campylobacter spp. to fluoroquinolones, which are generally used for the treatment of bacterial gastroenteritis, has increased during the past two decades, mainly as a result of the approval of this group of antimicrobials for use in food-producing animals. The aim is to determine the frequency of resistance of campylobacter to various antimicrobial agents and the relationship between antimicrobial agents of the isolates and the presence of plasmid. Twenty five Campylobacter isolates gotten from humans were subjected to antibiotics testing using Kirby Bauer disc diffusion method as well as standard E-test method. The plasmid profile of the isolates was determined using the Alkaline phosphatise procedure. The antimicrobial susceptibility testing of these isolates showed that all were sensitive to Erythromycin and Ciprofloxacin while none was sensitive to co-trimoxazole. The standard organisms were sensitive to co-trimoxazole $(80 \%)$ and ciprofloxacin $(65 \%)$ but were resistant to erythromycin $(70 \%)$. No plasmid was found in streptomycin and ampicillin resistant strains, with the exception of four isolates which were co-trimoxazole-resistant and which contained around $24.4 \mathrm{~kb}$ plasmids.
\end{abstract}

\section{Keywords}

Campylobacter, Antibiotics, Plasmids

How to cite this paper: Adekunle, O.C. and Onilude, A.A. (2015) Antimicrobial Resistance and Plasmid Profiles of Campylobacter Species from Infants Presenting with Diarrhoea in Osun State, Nigeria. Open Journal of Medical Microbiology, 5, 17-21. http://dx.doi.org/10.4236/ojmm.2015.51003 


\section{Introduction}

The most common human disease caused by Campylobacters is acute gastroenteritis [1]. A collective name for infectious disease caused by members of these bacteria is called Campylobacteriosis [2]. Campylobacter infections are among the most common bacterial infection in humans. It is characterized by profuse, often bloody diarrhoea, particularly in children, acute abdominal pain and fever. They produce both diarrheal and systemic illness.

Most cases recover after a period of bed rest like other enteric infections. It is usually cleared up on their own but sometimes is treated with electrolyte replacement and rehydration therapy. Antimicrobial treatment (erythromycin, tetracycline or fluoroquinolone) can be used in invasive cases to eliminate the carrier state. It can also shorten the duration of symptoms if given early in the illness [3]. Most clinical isolates of $C$. jejuni were reported to be resistant to ciprofloxacin and azithromycin [4]. However, antimicrobial resistance to clinically important drugs used for treatment (especially macrolides and fluoroquinolones) is increasingly reported for Campylobacters. There is evidence that patients infected with antibiotic-resistant strains suffer worse outcomes (invasive illness or death) than those infected with sensitive strains [5]. Antibiotic susceptibility studies are necessary because variation occurs from country to country and from place to place. Studies in Europe have shown $C$. jejuni to be sensitive in-vitro to antibiotics such as tetracycline, erythromycin, gentamycin while many strains are resistant to ampicillin, pencillin and metronidazole [6]. The development of antimicrobial resistance in the last four decades has led to an intensification of discussion about the prudent use of antimicrobial agents, especially in veterinary medicine, since their use and the development of resistance in human and animals are interrelated [7]. There is an increased rate of resistance to erythromycin, which is the drug of choice for the treatment of campylobacter enteritis. The resistance to erythromycin by these strains might be due to the presence of plasmid harboured by these organisms [8]. In this study, we present the occurrence of drug resistance among 25 strains of Campylobacter species isolated from children with diarrhoea. The frequency of plasmid as well as the relationship between antibiotic resistance and plasmid carriage was also investigated.

\section{Materials and Methods}

Stool samples were obtained from children with incipient diarrhoea between ages one month and 36 months. Faecal samples were cultured on Butzler-type medium which consisted of Butzler agar; $5 \%$ sheep blood; CAT from Oxoid comprised of cefoperazone, vancomycin and amphotericin B as selective agents. The incubation was done at $42^{\circ} \mathrm{C}$ for $72 \mathrm{hr}$ in a microaerophilic atmosphere using $\mathrm{CO}_{2}$ incubator (Sanyo $\mathrm{CO}_{2}$ incubator Model MCO-15A, Japan). The incubation was done in an atmosphere with reduced oxygen (5\%) with added carbondioxide (10\%) and $85 \% \mathrm{~N}_{2}$. The isolated strains were identified according to established criteria for Campylobacter species using biochemical tests [9].

\subsection{Antibiotic Sensitivity Testing of Isolates}

The antibiotics used included ampicillin (25 $\mu \mathrm{g})$, streptomycin $(10 \mu \mathrm{g})$, ciprofloxacin $(5 \mu \mathrm{g})$, nalidixic acid (30 $\mu \mathrm{g})$, erythromycin $(10 \mu \mathrm{g})$, tetracycline $(10 \mu \mathrm{g})$, gentamycin $(10 \mu \mathrm{g})$, co-trimoxazole $(25 \mu \mathrm{g})$, nitrofurantoin $(200 \mu \mathrm{g})$, ceftriazole $(30 \mu \mathrm{g})$ from Oxoid. The Kirby Bauer disc diffusion method for in vitro susceptibility testing was employed in this study. Media plates containing different colonies were inoculated and incubated. The inoculum compared with 0.5 Macfarland standard and Mueller-Hinton agar was used. The zones of inhibition of the test strains when comparable with the zone of inhibition of control organism were interpreted as sensitive, while those showing no zones of inhibition or narrower zones of inhibition than those of sensitive control organisms were interpreted as resistant. The antimicrobial susceptibility testing was also performed by using the standard E-test method. The bacterial inoculum was adjusted to 0.5 Macfarland standard turbidity using the Mueller Hinton agar. All plates were incubated at $37^{\circ} \mathrm{C}$ for 48 hours under microaerophilic conditions. Results were interpreted according to the Clinical Laboratory Standard Institute (CLSI) guidelines (CLSI document $\mathrm{M}$ 45-A and M 100-S17, clinical, 2006, 2007), using the following resistance break point of C.jejuni/coli: ampicilin $>16 \mathrm{mg} / \mathrm{L}$, Ciprofloxacin $>4 \mathrm{mg} / \mathrm{L}$, gentamicin $>16 \mathrm{mg} / \mathrm{L}$, erythromycin $>32 \mathrm{mg} / \mathrm{L}$ nalidixic acid $>32$ $\mathrm{mg} / \mathrm{L}$, and streptomycin $>16 \mathrm{mg} / \mathrm{L}$. The following reference strains were used as controls: $C$. jejuni subsp jejuni ATCC $2 \mathrm{q}_{28} 8^{\mathrm{TM}}$ and Campylobacter coli $\mathrm{ATCC}^{\mathrm{R}} 33559^{\mathrm{TM}}$ purchased from ATCC. 


\subsection{Plasmid Isolation}

Isolation of Plamids was done by Birnobiom and Doly Method (1984). Electrophoretic gels electrophresis was prepared by dissolving and boiling $1.0 \mathrm{~g}$ agarose in $100 \mathrm{ml} 1 \mathrm{X}$ TBE buffer solution. The gel was allowed to cool to about $45^{\circ} \mathrm{C}$ and $10 \mu \mathrm{l}$ of $5 \mathrm{mg} / \mathrm{ml}$ ethidium bromide was added, mixed together before pouring it into an electrophoresis chamber set with the combs inserted. After the gel has solidified, $10 \mu \mathrm{l}$ of the plasmids DNA and 2 $\mu \mathrm{l}$ of $6 \times$ loading dye was mixed together and loaded in the well created. Electrophoresis was carried out at $80 \mathrm{~V}$ for 1 hours. The plasmid was visualized and photographed on UV light source. Supercoiled DNA ladder (2 - 16 kb) (Life Technologies, Brazil) and plasmids of known molecular mass of Campylobacter coli (49, 3.9, and 3.4 kb) (Cabrita et al., 1992) were used to determine the approximate molecular mass of each plasmid. Those that carry plasmids were cured by treatment with sodium lauryl sulphate (SDS) (Tomoeda et al., 1968).

\subsection{Statistical Analysis}

Statistical analysis of obtained empirical results was done using Minitab 11.

\section{Results}

Twenty five Campylobacter isolates were obtained from human stool samples. All isolates were sensitive to erythromycin and ciprofloxacin but none was sensitive to co-trimoxazole (Table 1).

In the antibiotic susceptibility pattern of Campylobacter isolates in Table 1 Ciprofloxacin and Erythromycin were one hundred percent effective, followed reducingly by Cefriazole (84\%), Gentamycin and Nalidixic acid (82\% and 80\% respectively) Co-trimozale was totally ineffective against the Campylobacter isolates. Plate 1 shows the minimum inhibitory concentration of erythromycin by E test. Others were also done and the values gotten are reported in Table 1.

\section{Discussion}

The antimicrobial susceptibility testing of these isolates showed that (100\%) were sensitive to Erythromycin and Ciprofloxacin. This conforms to the study by [10] which has shown that Erythromycin and ciprofloxacin as the drugs of choice for the treatment of Campylobacter-related diarrhoea. [10]. People having diarrheoa showed high resistance to antibiotics like ampicillin, streptomycin, tetracycline and total resistance to co-trimoxazole. They are widely used in Nigeria even when they were not prescribed. Resistance to these drugs especially co-

Table 1. Frequency of Antibiotics susceptibility of the Campylobacter isolates from stool samples of infants presenting with diarrhoea-like symptoms.

\begin{tabular}{|c|c|c|c|c|c|}
\hline \multirow[t]{3}{*}{ Antibiotics } & \multicolumn{2}{|c|}{ Campylobacter } & \multirow[b]{3}{*}{ Susceptible isolate } & \multirow[b]{3}{*}{ MIC } & \multirow[b]{3}{*}{ Total } \\
\hline & \multicolumn{2}{|c|}{ Zone of inhibition } & & & \\
\hline & SS & RS & & & \\
\hline Ampicillin $25 \mu \mathrm{g}$ & $\geq 14 \mathrm{~mm}$ & $\leq 11 \mathrm{~mm}$ & 13 & $0.2 \mu \mathrm{g} / \mathrm{ml}$ & 25 \\
\hline Streptomycin $10 \mu \mathrm{g}$ & $\geq 15 \mathrm{~mm}$ & $\leq 11 \mathrm{~mm}$ & 12 & $4 \mu \mathrm{g} / \mathrm{ml}$ & 25 \\
\hline Ciprofloxacin $5 \mu \mathrm{g}$ & $\geq 21 \mathrm{~mm}$ & $\leq 15 \mathrm{~mm}$ & 25 & $0.025 \mu \mathrm{g} / \mathrm{ml}$ & 25 \\
\hline Nalidixic acid $30 \mu \mathrm{g}$ & $\geq 19 \mathrm{~mm}$ & $\leq 13 \mathrm{~mm}$ & 20 & $4 \mu \mathrm{g} / \mathrm{ml}$ & 25 \\
\hline Erythromycin $10 \mu \mathrm{g}$ & $\geq 23 \mathrm{~mm}$ & $\leq 13 \mathrm{~mm}$ & 25 & $2 \mu \mathrm{g} / \mathrm{ml}$ & 25 \\
\hline Tetracyline $30 \mu \mathrm{g}$ & $\geq 19 \mathrm{~mm}$ & $\leq 14 \mathrm{~mm}$ & 18 & $0.3 \mu \mathrm{g} / \mathrm{ml}$ & 25 \\
\hline Gentamycin $10 \mu \mathrm{g}$ & $\geq 15 \mathrm{~mm}$ & $\leq 12 \mathrm{~mm}$ & 20 & $0.25 \mu \mathrm{g} / \mathrm{ml}$ & 25 \\
\hline Cotrimoazole $25 \mu \mathrm{g}$ & & & 0 & & \\
\hline Nitrofurantoin $200 \mu \mathrm{g}$ & & $\leq 14 \mathrm{~mm}$ & 18 & $5 \mu \mathrm{g} / \mathrm{ml}$ & 25 \\
\hline Ceftriaxone $30 \mu \mathrm{g}$ & & $\leq 13 \mathrm{~mm}$ & 21 & $6 \mu \mathrm{g} / \mathrm{ml}$ & 25 \\
\hline
\end{tabular}




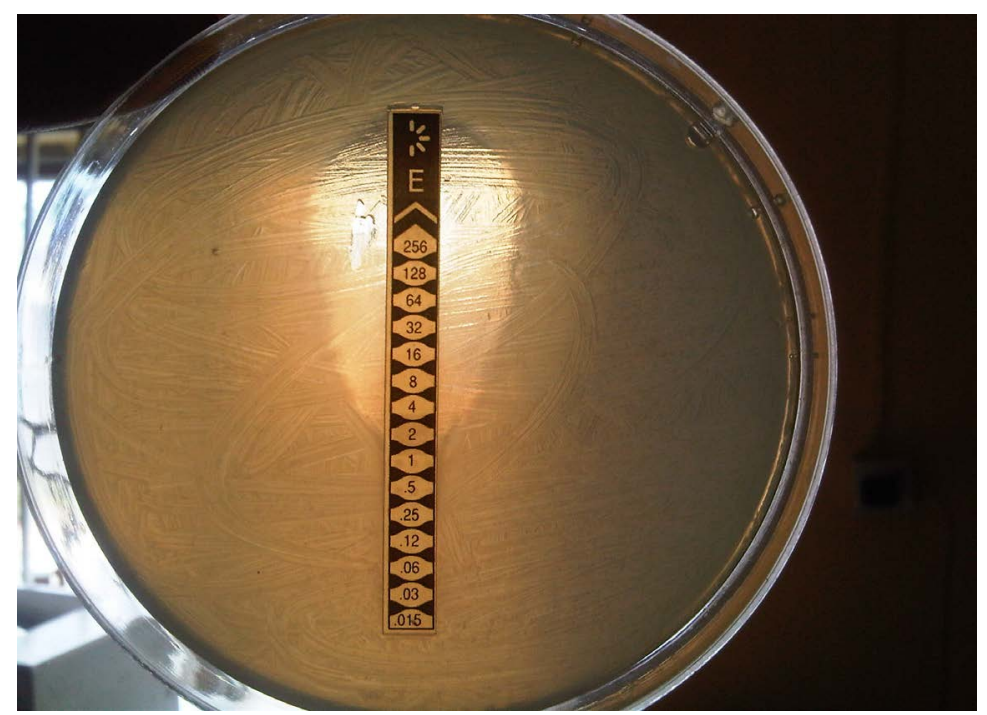

Plate 1. Minimum inhibitory concentration by E-test of erythromycin antibiotic for Campylibacter jejuni.

trimoxazole is common in this part of the world because there are no guidelines and controlled access to drugs, situation that can lead to development of resistance even where there are guidelines, the regulatory agencies are inefficient. The use of these drugs for infections other than gastroenteritis along with self-medication is often the causes of resistance in developing countries. In developed countries, resistance is due to their use in food animals and travel to developing countries. The increase in erythromycin resistance in developed countries is often low and stable at approximately $1 \%$ to $2 \%$ which is the reverse for developing countries [11]. For example, in 1984, 82\% of Campylobacter strains from Lagos, Nigeria, were reported sensitive to erythromycin which 10 years later came down to only $20.8 \%$ were sensitive [12]. In addition, resistance to another macrolide, azithromycin, was observed in 7\% to 15\% of Campylobacter isolates in 1994 and 1995 in Thailand [4]. Antibiotic susceptibility profile of microorganisms vary from country to country, province to province, town to town, and hospital to hospital in the same town as well as between private and public health-care facilities in the same area [13]. In addition, different pathologies may alter antibiotic sensitivity patterns. Consequently, periodic evaluation of antibiotic susceptibility is recommended to guide management of patients requiring antibiotic treatment. The $100 \%$ sensitivity of erythromycin in this environment maybe due to the fact that the drug is not abused unless it is prescribed, people do not buy and use unlike cotrimoxazole. Results of plasmid analysis to determine presence of extra chromosomal genes that may confer resistance on the organisms showed four [4] isolates presenting with plasmids. There is the possibility of the other isolates losing their plasmids during the tests. No plasmids were found in streptomycin-resistant and ampicillin-resistant strains, with the exception of four isolates which contained a $24.4 \mathrm{~Kb}$ plasmid and were co-trimoxazole-resistant. There was apparent relationship between carriage of plasmid and antimicrobial resistance because the isolates that possessed the plasmids were those that were resistant to cotrimoxazole and were of the same molecular size of $24.4 \mathrm{~kb}$.

Furthermore, plasmid analysis of the isolates showed that some of them possessed extra chromosomal gene of about $24.4 \mathrm{~kb}$ that could have conferred multi-resistance on them. The p value of those that possessed plasmid and non carriers of plasmids were determined. It was not significant.

\section{Acknowledgements}

The authors thank Prof. A. A. Onagbesan and all the staff of Biotechnology Department, Federal University of Agriculture, Abeokuta for their contributions towards the success of the work.

\section{References}

[1] Kosek, M., Bern, C. and Guerrant, R.L. (2003) The Global Burden of Diarrheal Disease, as Estimated from Studies Published between 1992 and 2000. Bulletin of the World Health Organization, 81, 197-207. 
[2] Coker, A.O. and Adefeso, A.O. (1994) The Changing Patterns of Campylobacter jejuni/coli in Lagos, Nigeria after Ten Years. East African Medical Journal, 71, 437-440.

[3] Murphy Jr., G.S., Echeverria, P., Jackson, L.R., Arness, MK., LeBron, C. and Pitarangsi, C. (1996) Ciprofloxacin- and Azithromycin-Resistant Campylobacter Causing Traveler's Diarrhea in US Troops Deployed to Thailand in 1994. Clinical Infectious Diseases, 22, 868-869. http://dx.doi.org/10.1093/clinids/22.5.868

[4] Hoge, C.W., Gambel, J.M., Srijan, A., Pitarangsi, C. and Echeverria, P. (1998) Trends in Antibiotic Resistance among Diarrheal Pathogens Isolated in Thailand over 15 Years. Clinical Infectious Diseases, 26, 341-345. http://dx.doi.org/10.1086/516303

[5] Helms, M., Simonsen, J., Olsen, K.E. and Molbak, K. (2005) Adverse Health Events Associated with Antimicrobial Drug Resistance in Campylobacter Species: A Registry-Based Cohort Study. Journal of Infectious Diseases, 191, 10501055. http://dx.doi.org/10.1086/428453

[6] Samuel, M.C., Vugia, D.J., Shallow, S., Marcus, R., Segler, S., McGivern, T., Kassenborg, H., Reilly, K., Kennedy, M., Angulo, F. and Tauxe, R.V., Emerging Infectious Program Food Net Working Group (2004) Epidemiology of Sporadic Campylobacter Infection in the United States and Declining Trend in Incidence. Food Net. 1996-1999. Clinical Infectious Diseases, 38, S165-S174. http://dx.doi.org/10.1086/381583

[7] Caprioli, A., Busani, L., Martel, J.L. andHelmuth, R. (2000) Monitoring of Antibiotic Resistance in Bacteria of Animal Origin: Epidemiological and Microbiological Methodologies. International Journal of Antimicrobial Agents, 14, 295301. http://dx.doi.org/10.1016/S0924-8579(00)00140-0

[8] Stern, N.J., Patton, C.M., Doyle, M.P., Park, C.E. and McCardell, B. (1992) Campylobacter. In: Vanderzant, C. and Splittstoesser, D.F., Eds., Compendium of Methods for the Microbiological Examination of Foods, American Public Health Association, Washington DC, 475-489.

[9] Engberg, J, Aarestrup, F.M., Taylor, D.E., Gerner-Smidt, P. and Nachamkin, I. (2001) Quinolone and Macrolide Resistance in Campylobacter jejuni and C. coli: Resistance and Trends in Human Isolates. Emerging Infectious Diseases Journal, 7, 24-34. http://dx.doi.org/10.3201/eid0701.010104

[10] Feierl, G., Wagner, U., Sixl, B., Grisold, A., Daghofer, E. and Marth, E. (2001) Epidemiology of campylobacteriosis and Development of Resistance in Styria. Austria. International Journal of Medical Microbiology, 291, 9.

[11] Cabrita, J., Rodrigues, J., Braganc Ëa, F., Morgado, C., Pires, I. and Gonc Ëalves, A.P. (1992) Prevalence of Biotypes, Plasmid Profile and Antimicrobial Resistance of Campylobacter Isolated from Wild and Domestic Animals from Northeast Portugal. Journal of Applied Bacteriology, 73, 279-285. http://dx.doi.org/10.1111/j.1365-2672.1992.tb04978.x

[12] Coker, A.O. and Adefeso, A.O. (1994) The Changing Patterns of Campylobacter jejuni/coli in Lagos, Nigeria after Ten Years. East African Journal Medicine, 71, 437-440.

[13] Sein, P.P., Hoosen, A.A., Crew-Brown, H.H., Coovadia, Y., Dove, M.G., Heidi, O., Koornhof, H.J., Oliver, S., Perovic, O., Prinsloo, B., Janse van Rensburg, M.N., Simpson, J., Sturm, A.N., Wadula, J. and Wasserman, E. (2005) Antimicrobial Susceptibility Profile of Selected Invasive Pathogens from Academic Hospitals of South Africa for the Ten Years 2001-2004. Southern African Journal of Infectious Diseases, 20, 85-89. 